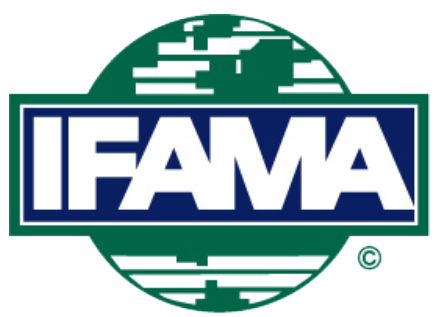

International Food and Agribusiness Management Review

Volume 24, Issue 3, 2021; DOI: 10.22434/IFAMR2021.0041

Received: 1 April 2021 / Accepted: 8 November 2021

\title{
Brazilian farmer confidence in business performance
}

\section{RESEARCH ARTICLE}

\author{
Caetano Haberli Júnior ${ }^{\mathrm{a}}$ (D), Eduardo Eugênio Spers ${ }^{(1)}{ }^{\mathrm{iD}}$, Lilian Maluf de Lima $^{\mathrm{b}}$ (iD), \\ Débora da Costa Simões ${ }^{\mathrm{c}}$ (iD) and Marcos Fava Neves ${ }^{\mathrm{d}}$ (D) \\ ${ }^{a}$ Researcher, University of São Paulo (USP), Guarujá Street 240, Vinhedo, SP, CEP 13287-154, Brazil
}

${ }^{b}$ Professor, ${ }^{c}$ Researcher, University of São Paulo (USP), Luiz de Queiroz College

of Agriculture (ESALQ), Departament Economics, Administration and Sociology

(LES), Pádua Dias Avenue 11, Piracicaba / SP, CEP 13418-900, Brazil

${ }^{d}$ Professor, University of São Paulo (USP), FEARP School of Business, Bandeirantes Avenue 3900, Ribeirão Preto / SP, CEP 14040-900, Brazil

\begin{abstract}
The aim of this article is to understand how rural producers in Brazil generate their investment expectations in terms of their costs, productivity, and other macroeconomic variables related to agricultural production. This study contributes to the formulation of more efficient public policies that take into account not only market information, but also the expectations of farmers. Based on data from a survey that calculates the rural producer confidence index in Brazil, non-parametric tests were performed to assess the equality of responses attributed by them in different periods, configured as crop development and harvest start, during 2014 and 2017. The results indicate that the farmer's behavior is sensitive to changes in the market and his business. Productivity is seen as a long-term expectation. The cost of production and the sale price have generated short and medium-term expectations.
\end{abstract}

Keywords: expectations, farmer's confidence, Brazil, public agricultural policies JEL code: Q10, E2, J38

\footnotetext{
${ }^{\circledR}$ Corresponding author: edespers@usp.br
} 


\section{Introduction}

Economists have been trying to understand and weigh consumer sentiments for some time (Ludvigson, 2004). Consumer behavior generates an important component in the analysis of macroeconomic dynamics (Ghosh, 2020). Therefore, it is pertinent to discuss how the farmer's trust motivates the behavior of their investments in a business-to-business perspective, which can decide the economic functioning of food production in Brazil and the formulation of public policies. Ludvigson (2004) recalls that as early as 1936, John Maynard Keynes discussed and pondered the ways in which consumers' feelings and expectations can influence the real economy.

The behavior of consumers and other economic agents generates an important component in the analysis of macroeconomic dynamics (Ghosh, 2020; Ludvigson, 2004) and consequently allows for subsidizing public policies. Keynes (1936) already discussed and pondered the ways in which consumers' feelings and expectations can influence the real economy. The reverse is also true, institutions are influential in the rules of the game and players will make their decisions according to these rules (North, 1990). The theory of planned behavior (TPB) is a reasoned action approach (Fishbein and Ajzen, 2010), that is a well-known and frequently applied framework for explaining and predicting human behavior. It focuses on the controlled aspects of decision-making and on behaviors that are goal-directed and steered by conscious self-regulatory processes.

Intuition, in turn, is a critical component of farmers' decision-making, and developing successful intuition requires extensive consultancy, personal and critical reflection on an ever-evolving decision-making skill (Nuthall and Old, 2018).

Thus, the article intends to understand how the behavior of soybean producers in Brazil generates their investment expectations and what lessons from these behaviors can allow the formulation of more objective public policies for the availability of credit, financing and rural insurance. The objective is to assess whether the farmer takes into account, in his decision based on general economic conditions (GEC) and farm conditions (FC), from the perspective of the theory of planned purchase, the expectations or confidence in the current, past and future factors of the environment and your business.

Specifically, it is intended: (a) describe a confidence index that is structured specifically for the Brazilian agricultural sector, but that can be a reference for other contexts and countries; (b) understand the expectations for an economic agent that is considered organizational, but that incorporates personal aspects in his decision; and (c) propose an analytical model to measure if the decision is made by the theory of planned behavior or made by intuition behavior between expectations and expectations for two different years and the performance accomplishment for subsequent periods (expectations and performance in the harvest).

This article has three main contributions to the literature. The first is to describe a confidence index that is structured specifically for the Brazilian agricultural sector, but that can be a reference for other contexts and countries. Brazilian agriculture is one of the most competitive and efficient in the world and the decisionmaking process is professionalized (Junior et al., 2019). The confidence indexes contribute to a better understanding of the functioning of the markets, but the agricultural sector is lacking in this type of indicator, perhaps due to the difficulty of collecting and accessing information. Most indicators are intended for the end consumer, industry or retail (Chernavsky, 2018).

The second contribution is to understand the expectations for an economic agent that is considered organizational, but that incorporates personal aspects in his decision (Haberli Junior et al., 2019a,b). Agricultural activity is influenced by variables that cause a series of risk perceptions to its main decision maker, the farmer. Although it is considered an organizational decision, agricultural activity can be influenced by the personal characteristics of the farmer. In addition, the variables that affect decision making are common (climate, price, economy, for example) and influenced by a regular seasonality (planting and harvest time), different from what happens with the complex and differentiated dynamics between industries and the final 
consumer (Graminho, 2015; Simões et al., 2016). Therefore, it is pertinent to discuss how the farmer's confidence influences his expectations from a business-to-business perspective.

The third contribution is to propose an analytical model to measure the type of behavior between expectations and expectations for two different years and the performance accomplishment for subsequent periods (expectations and performance in the harvest).

The results contribute to the formulation of public policies aimed at the agricultural sector, especially those aimed at credit and rural insurance. As the variables are common, the analysis of a more comprehensive historical series than the one evaluated in this study, may allow to identify predictable behaviors in advance, which also makes it possible to define public policies in advance by the government and some private interest organizations such as cooperatives and associations of rural producers and industries linked to the agricultural sector.

In addition to this brief introduction, item two describes the index studied (the ICAGRO). Following the methodology, the study results and finally the conclusions are presented.

\section{Theoretical foundation}

The basis for monitoring the cycles of economic dynamics and analyzing the business climate of a given sector are the entrepreneur's confidence indices (Los and Ocheretin, 2019). The evaluation of these indicators makes it possible to predict crisis or investment phenomena and develop possible solutions to difficult situations. Agriculture is characterized by a volatile environment. Numerous risks are taken by producers to supply commodities that are bought and sold by various parts of the supply chain (Turner V, 2018). These three points justify studying a model that can assess farmer confidence in Brazil.

\subsection{Brazilian agribusiness}

Agribusiness is inserted in the Brazilian export and import trade relations in a relevant way, mainly due to the soy complex (Dos Santos Amorim et al., 2019). Brazil is one of the market players in the production of vegetable proteins, animal proteins, energy and fiber in the world (Junior et al., 2019).

The strategic emphasis on food security and safe food grows with the permanent defense of the United Nations organization (www.ONU.org) to guarantee access to food for the entire planet, as a demand that can ensure world peace (http://agenciabrasil.ebc.com.br; http://www.fao.org) (FAO, 2020). A study shows that important advances in modeling of agricultural systems occurred when there were concerns about food security or other crises such as major disasters and then slowed down (Jones et al., 2017). Perhaps, what will connect 8 billion people in the world is not just the Internet, but food chains, organized, restructured and realigned.

Brazil plays an important role in this process (OECD-FAO Agricultural Perspectives 2011-2020, 2011). The Organization for Economic Co-operation and Development (OECD) recognizes in its Outlook 2011-2020 that the world food supply will have to grow $20 \%$ so that there is no hunger in the world. For the world to grow $20 \%$, Brazil will have to grow $40 \%$ in this offer.

In this context, some indicators gain relevance to sustain this challenge. A strategic plan to define public policies for agribusiness must contain the evaluation of these indicators: productivity, selling price, inputs costs, cultivated area, credit availability, country economy, development of the farm and farm region, considering the investment perspectives of the farmer. 


\section{The Rural Producer Confidence Index}

In 2013, the Rural Producer Confidence Index (ICAGRO) was created with the objective of presenting information about the current perception and future perspectives of the farmer. These perceptions and expectations are canvassed among farmers, between input companies (before the farm gate) and production purchasing companies (after the farm gate). However, this article will only analyze the results of the farmers (within the farm gate). The collection of information for the preparation of this confidence indicator is carried out on a quarterly basis.

ICAGRO's analyzes include the variables of the components of the current situation and future expectations from two economic perspectives: farm conditions (FC) and general economic conditions (GEC).

In each ICAGRO survey, five questions are asked to the farmers to assess the current conditions of the farm (Table 1). The components of the current situation show an instant photograph of the moment of the farmers' response.

On the component side for general economic conditions, the survey also considers a photograph of the current moment shown in Table 2. Three questions were asked of the farmers.

\subsection{Expectations components}

Also in each ICAGRO component for expectations, farmers were asked questions to assess the farm's expectations for the future. The expectations components can evaluate the investment and economic growth conditions for the sector. As with the components of the current situation, the components of expectations measure both farm conditions and economic conditions. Table 3 shows how the issues are raised.

Table 1. Components of current analysis of farm conditions.

On a scale of 1 to 5 , where 1 means way below the expected and 5 means way above the expected, at this moment how is the current production conditions.

\begin{tabular}{llrrrrr}
\hline & & $\begin{array}{c}\text { Way below } \\
\text { the expected }\end{array}$ & $\begin{array}{c}\text { Way above } \\
\text { the expected }\end{array}$ \\
\hline 1 & The productivity of your crop is & 1 & 2 & 3 & 4 & 5 \\
2 & The selling price of your production is & 1 & 2 & 3 & 4 & 5 \\
3 & $\begin{array}{l}\text { The costs of inputs (pesticides, fertilizers, correctives, seeds, diesel oill, } \\
\text { labor) used on your property are }\end{array}$ & 1 & 2 & 3 & 4 & 5 \\
4 & The planted area of their crops is & 1 & 2 & 3 & 4 & 5 \\
5 & A credit offer is & 1 & 2 & 3 & 4 & 5 \\
\hline
\end{tabular}

Table 2. Components of current analysis of the general economic conditions of the farms.

On a scale of 1 to 5 , where 1 means much worse and 5 means much improved, at this point you would say that the general conditions regarding the items below:

\begin{tabular}{llrrrrr}
\hline & & $\begin{array}{c}\text { Much } \\
\text { worse }\end{array}$ & & & $\begin{array}{c}\text { Much } \\
\text { improved }\end{array}$ \\
\hline 1 & Your segment / business & 1 & 2 & 3 & 4 & 5 \\
2 & From your region & 1 & 2 & 3 & 4 & 5 \\
3 & The Brazilian economy & 1 & 2 & 3 & 4 & 5 \\
\hline
\end{tabular}


Table 3. Components of analysis of future expectations of farm conditions and economic conditions. On a scale of 1 to 5, where 1 means way below than planned, and 5 means way above than planned what are the expectations for the next harvest in relation to your business, in the following components:

\begin{tabular}{|c|c|c|c|c|c|}
\hline & & $\begin{array}{l}\text { Way below } \\
\text { than } \\
\text { planned }\end{array}$ & & & $\begin{array}{r}\text { Jay above } \\
\text { than } \\
\text { planned }\end{array}$ \\
\hline 1 & The productivity of your crop will be & 1 & 3 & 4 & 5 \\
\hline 2 & The selling price of your production will be & 1 & 3 & 4 & 5 \\
\hline 3 & $\begin{array}{l}\text { The costs of inputs (pesticides, fertilizers, correctives, seeds, diesel oil, } \\
\text { labor) used on your property will be }\end{array}$ & 1 & 3 & 4 & 5 \\
\hline 4 & The planted area of your crops will be & 1 & 3 & 4 & 5 \\
\hline 5 & The credit offer is & 1 & 3 & 4 & 5 \\
\hline
\end{tabular}

On a scale of 1 to 5 , where 1 means very pessimistic, and 5 very confident, what is your perspective for the next harvest in relation to general economic conditions:

\begin{tabular}{llrrrrrr}
\hline & & \multicolumn{2}{c}{$\begin{array}{c}\text { Very } \\
\text { pessimistic }\end{array}$} & & \multicolumn{4}{c}{$\begin{array}{c}\text { Very } \\
\text { confident }\end{array}$} \\
\hline 1 & Your segment / business & 1 & 2 & 3 & 4 & 5 \\
2 & From your region & 1 & 2 & 3 & 4 & 5 \\
3 & The Brazilian economy & 1 & 2 & 3 & 4 & 5 \\
\hline
\end{tabular}

\subsection{Investment components}

To assess investments, farmers are asked to rate, on a scale between 1 and 5, where 1 means totally disagree and 5 means totally agree, four statements: (1) I intend to invest more to increase the technological standard of my crops in seeds, fertilizers and pesticides this season; (2) I want to invest more in machinery and equipment on my property (ies) in the coming months; (3) I am investing more in infrastructure per hectare on my farm(s); (4) I will invest more in labor and people management on my farm(s).

\subsection{Sample size and survey procedures}

The sample size is formed with 695 respondents. Of these, 645 are farmers: 100 ranchers (beef cattle and dairy cattle), 545 farmers and 50 companies that supply inputs or purchase production. It is important to note that for the calculation of panel A (farmers) a weighting of $75 \%$ is used for the responses of farmers and $25 \%$ for the responses of ranchers. This is based on the gross production value (GPV) of these segments. The sample is divided by cultivation and in the main producing states in Brazil.

The sample includes small, medium and large producers and represents producers who are responsible for forming the GPV of Brazilian agriculture. They are consumers of technology and services from industries, cooperatives and represent the dynamism of the sector. The sample size for each culture and region was defined in line with its respective participation in the GPV. Regarding the size of the properties, the following stratification between small, medium and large properties was adopted, according to the productive reality of each State and the experiences of the researchers. Data collection is carried out every 3 months and has been released since the fourth quarter of 2013. A structured data collection instrument is used for the quantitative survey of data in personal interviews and by telephone.

For the studies of the questions in this article, only surveys farmers were analyzed. The samples in the quarters analyzed in this article are indicated in the tables in section 5 that deals with the results and discussions. 


\subsection{Construction of ICAGRO}

The disclosure of ICAGRO's results can be seen on the website www.icagro.com.br. It is important to note that the planted area component is not part of the final calculation of ICAGRO. This component is being used only as a control variable. However, this article considers the component / variable called the planted area to collaborate with our analysis and validation of our hypotheses.

Empirically it is built to total 200 points. Above 100 points, farmers are optimistic. Below 100 points, farmers are pessimistic. The amount disclosed each semester is $(\Sigma 1 \times 0)+(\Sigma 2 \times 50)+(\Sigma 3 \times 100)+(\Sigma 4 \times 150)$ $+(\Sigma 5 \times 200) /(\Sigma 1+\Sigma 2+\Sigma 3+\Sigma 4+\Sigma 5)$. In other words, the responses of interviewed classified as 1 receive zero weight, 2 weight 50, 3 weight 100, 4 weight 150 and 5 weight 200. With that, we created an indicator that goes from zero to two hundred. In addition, current conditions weigh $30 \%$ and expectations $70 \%$. This applies to both FC and GEC. Also, for general economic conditions a weight of $70 \%$ is computed and for farm conditions a weight of $30 \%$.

Within the general economic conditions, the following weighted weights are defined: the economy of Brazil with $70 \%$, the region with $15 \%$ and the sector with $15 \%$. This decision considers that the weight of the GEC has greater importance for the investment decision criteria in relation to the FC.

\section{Methods}

Among the farmers, the sample is divided considering the plant crop component as follows: Soy $28 \%$, Sugarcane $19 \%$, Corn $19 \%$, Coffee $9 \%$, Cotton $6 \%$, Rice $3 \%$, Citrus $3 \%$ and Wheat $1 \%$. For the region component, the sample is divided into: South $25 \%$, Southeast $30 \%$, Midwest $35 \%$ and North and Northeast $10 \%$.

For the farm size component, the sample includes small, medium and large producers. These farmers have the profile of being consumers of technology and services from industries, cooperatives and represent the dynamism of the sector. The sample size for each crop and region was defined in line with their respective share of the GPV. In relation to the size of the properties, a stratification was adopted to define small, medium and large farms, according to the productive reality of each State, with the experiences of researchers and the continental dimension of Brazil. This definition can be evaluated and discussed, as shown in Table 4. Data collection is carried out every 3 months and has been released since the fourth quarter of 2013. A structured data collection instrument is used for the quantitative survey of data in personal interviews and over the phone.

For the studies of the questions in this article, only surveys with farmers were analyzed. The samples in the quarters analyzed in this article are indicated in the Tables of the chapter dealing with the results and discussions.

Table 4. Definition for property sizes. ${ }^{1}$

\begin{tabular}{lccc}
\hline State $^{2}$ & Small (*) & Medium (*) & Big (*) \\
\hline PR, SC, RS, SP, MG, ES, PE, AL & $<100$ & 100 to 500 & $>500$ \\
GO e MS & $<500$ & 501 to 3,000 & $>3,000$ \\
PA, MT, MA, PI, TO, West of BA & $<1000$ & 1,001 to 5,000 & $>5,000$ \\
\hline 1 (*) area in acres; source: www.icagro.com.br & & \\
${ }^{2}$ AL=Alagoas; BA=Bahia; ES=Espírito Santo; GO=Goiás; MA=Maranhão; MG=Minas Gerais; MS=Mato Grosso do Sul; MT=Mato \\
Grosso; PA=Pará; PE=Pernanbuco; PI=Piauí; PR=Paraná; RS=Rio Grande do Sul; SC=Santa Catarina; SP=São Paulo; TO=Tocantins.
\end{tabular}


Non-parametric tests (Wilcoxon) were carried out, obtaining results with a statistical basis to evaluate the equality of the grades attributed by coffee, orange, rice, soy, corn and cotton producers, in different periods in situations 1 and 2. On situation 3, we considered the responses of the soy farmers, so the situations are thus defined:

- Comparison of notes regarding the expectations of farmers in the period of crop development and beginning of harvest $\left(1^{\text {st }}\right.$ quarter) between the years $2014 \times 2015,2015 \times 2016,2016 \times 2017$;

- Comparison of notes referring to farmers' expectations in the end of the harvest period and planning of the future harvest ( $3^{\text {rd }}$ quarter) between the years $2014 \times 2015$ and $2015 \times 2016$;

- Comparison of notes referring to the expectations of producers collected in the period of beginning planting ( $3^{\text {rd }}$ quarter) for the performance of farmers at the beginning of the harvest ( $1^{\text {st }}$ quarter), between the years $2014 \times 2015,2015 \times 2016$ and $2016 \times 2017$. Here the objective is to verify the equality between what is expected and what has been accomplished between soy farmers.

In these 3 situations, variables from 3 groups were compared:

- crop conditions (productivity, selling prices, input costs, cultivated area and credit availability);

- general conditions (business, region / state and Brazilian economy); and

- investment.

The Wilcoxon test (Mann-Whitney) is a non-parametric test that can be used to determine whether two independent samples were selected from populations that have the same distribution (Larson and Farber, 2010). The techniques of non-parametric statistics are adaptable to data from behavioral science (Siegel, 1956). For the author, the application of these techniques does not require assumptions regarding the distribution of the population variable. Thus, non-parametric tests are interesting for the analysis of qualitative data, which do not require normal distribution and where the samples may have a small size (less than 25 pieces of information).

The Wilcoxon test requires that the analyzed variable be measured on an ordinal or numerical scale and can be ordered (Bussab and Moretin, 2006). The values of the variable in question (notes) are stacked for the two independent samples and ordered. From this order, a rank is assigned: the lowest score value, rank 1 is assigned; to the next, rank 2 and so on (in ascending order). Then, these ranks must be added according to the two samples to which they belong and which will be compared. Thus, two sums of ranks are obtained, called ' $R$ '. For the test in question, according to the related literature (Larson and Farber, 2010), the ' $R$ ' for the smallest sample should be considered for the calculation of the test statistic. If the samples are the same size, the choice of ' $R$ ' will be irrelevant.

Thus, the calculated ' $R$ ' value will be standardized (subtracting the average and dividing by the standard deviation, according to equation 1), and can be analyzed using the standardized normal distribution (z).

If there is a statistical difference between the sums (R) of the two samples, it can be expected that the samples are not equivalent, rejecting the null hypothesis $\left(\mathrm{H}_{0}\right)$, at an established level of significance.

Wilcoxon tests were performed in each of the three situations mentioned, aiming to analyze the difference in grades of producers, between the years 2014 to 2017.

From the data samples, the Wilcoxon test was performed, evaluating the grades of the producers of two samples analyzed, within each situation. The hypotheses considered in each test were: the null hypothesis $\left(\mathrm{H}_{0}\right)$ that there is no difference in the scores given by farmers (Sample 1 in comparison with Sample 2), against the alternative hypothesis (Ha) that there is a difference in these notes.

Initially, a two-tailed test was performed. Only in the case of this test being significant (showing difference in the samples), a single-tailed test was applied, evaluating whether sample 1 was smaller or larger than sample 2 (data that are different). The software used to perform the tests was the R Program (R Core Team, 2018). 


\section{Results and discussion}

The analysis of the test results for expectations (Tables 4, 5 and 6) compares expectations in period t1 with expectations in period $t_{1}$ with expectations in period $t_{1+1}$, explained in situation 1. Situation 2 (Tables 7 and 8) compares expectations for the end of the harvest in the period $t_{2}$ with expectation in period $t_{2+1}$.

\subsection{Situation 1: comparisons of expectations at the beginning of the harvest ( $1^{\text {st }}$ quarter)}

This period in Brazil is considered as the time of crop development and the beginning of the harvest. First, it was possible to compare, from a statistical point of view, whether the farmers' notes between two samples, according to the three situations analyzed, are considered equal or not. The results were obtained from the application of the Wilcoxon tests for independent samples referring to scores attributed by the interviewed producers. Therefore, for the first situation, the results are shown in Tables 5 to 7 .

Analyzing the three situations in Table 4, the null hypothesis of equality of grades was rejected (two-tailed test) in the analysis of all variables and, applying the same tests under one-tailed aspect (Ei,1 $\geq$ Ei,1), negative dissonance was observed for the analysis of the vast majority of variables.

In view of these results, it was observed that all expectations changed at the beginning of the harvest when comparing 2015 with 2014. For the economic scenario, a pessimistic behavior of expectations was observed in the three attributes analyzed (GEC). In the specific scenario (FC) the same behavior could also be observed, however, the long-term variable given by productivity was the only one that showed an optimistic variation in relation to 2014 .

It is noteworthy that the variable 'costs with inputs' had a higher expectation in 2015 compared to 2014 (reverse conclusion given the evidence of expectations). This denotes a pessimistic scenario because in 2015 higher expectations for producer costs were obtained compared to 2014. According to the USDA, the

Table 5. Expectation in $2014\left(1^{\text {st }}\right.$ quarter $) \times$ expectation in $2015\left(1^{\text {st }}\right.$ quarter $)$ - agricultural products. ${ }^{1}$

\begin{tabular}{|c|c|c|c|c|c|c|}
\hline Variables & $\begin{array}{l}\text { Expectation } \\
\left(E_{\mathrm{ij}}\right)^{2}\end{array}$ & $\begin{array}{l}\text { Expectation } \\
\left(E_{i j}\right)^{2}\end{array}$ & $\begin{array}{l}\text { R } \\
\text { (calculated } \\
\text { statistic) }\end{array}$ & $\begin{array}{l}H_{0}: E_{1,1}=E_{2,1} \\
H_{A}: E_{1,1} \neq E_{2,1} \\
\text { (two-tailed) }\end{array}$ & $\begin{array}{l}H_{0}: E_{1,1} \geq E_{2,1} \\
H_{A}: E_{1,1}<E_{2,1} \\
\text { (one-tailed) }\end{array}$ & Conclusion $^{3}$ \\
\hline \multicolumn{7}{|c|}{ General economic conditions } \\
\hline Business & Collected in & Collected in & 162,010 & $0.000^{*}$ & $0.999^{\mathrm{NS}}$ & $\mathrm{E}_{1,1}>\mathrm{E}_{2,1}$ Pessimistic \\
\hline State/region & $2014\left(1^{\text {st }} Q\right)^{5}$ & $2015\left(1^{\text {st }} Q\right)^{5}$ & 167,100 & $0.000^{*}$ & $0.999^{\mathrm{NS}}$ & $\mathrm{E}_{1,1}>\mathrm{E}_{2,1} \quad$ Pessimistic \\
\hline Brazilian & $\mathrm{n} 1=519$ & $\mathrm{n} 2=546$ & 216,660 & $0.000 *$ & $0.999^{\mathrm{NS}}$ & $\mathrm{E}_{1,1}>\mathrm{E}_{21} \quad$ Pessimistic \\
\hline \multicolumn{7}{|l|}{ Farm conditions } \\
\hline Productivity & Collected in & Collected in & 12,167 & $0.000 *$ & $0.000^{*}$ & $\mathrm{E}_{1,1}<\mathrm{E}_{2,1} \quad$ Optimistic \\
\hline Selling price & $2014\left(1^{\mathrm{st}} \mathrm{Q}\right)^{5}$ & $2015\left(1^{\text {st }} Q\right)^{5}$ & 165,780 & $0.000^{*}$ & $0.999^{\mathrm{NS}}$ & $\mathrm{E}_{1,1}>\mathrm{E}_{2,1}$ Pessimistic \\
\hline Inputs costs ${ }^{4}$ & $\mathrm{n} 1=519$ & $\mathrm{n} 2=546$ & 82,092 & $0.000^{*}$ & $0.000^{*}$ & $\mathrm{E}_{1,1}<\mathrm{E}_{2,1} \quad$ Pessimistic \\
\hline Cultivated area & & & 170,070 & $0.000 *$ & $0.990^{\mathrm{NS}}$ & $\mathrm{E}_{1,1}>\mathrm{E}_{2,1} \quad$ Pessimistic \\
\hline Credit availability & & & 157,090 & $0.000^{*}$ & $0.990^{\mathrm{NS}}$ & $\mathrm{E}_{1,1}>\mathrm{E}_{2,1} \quad$ Pessimistic \\
\hline Investment & & & 160,570 & $0.001 *$ & $0.999^{\mathrm{NS}}$ & $\mathrm{E}_{1,1}>\mathrm{E}_{2,1} \quad$ Pessimistic \\
\hline \\
\hline \multicolumn{7}{|c|}{${ }^{2} \mathrm{i}=$ year $\left(1,2,3\right.$ and 4 for $2014,2015,2016$ and 2017 , respectively); $\mathrm{j}=$ quarter ( 1 and 3 for $1^{\text {st }}$ and $3^{\text {rd }}$, respectively). } \\
\hline \multicolumn{7}{|c|}{${ }^{3}$ Conclusion $=$ dissonance in relation to the same quarter of the previous year. } \\
\hline \multicolumn{7}{|c|}{$\begin{array}{l}{ }^{4} \text { Input costs = when the evidence for the subsequent period is greater than the previous period, a pessimistic conclusion is reached } \\
\text { (higher cost expectations) }\end{array}$} \\
\hline
\end{tabular}


Table 6. Expectation in $2015\left(1^{\text {st }}\right.$ quarter $) \times$ expectation in $2016\left(1^{\text {st }}\right.$ quarter $)$-agricultural products. ${ }^{1}$

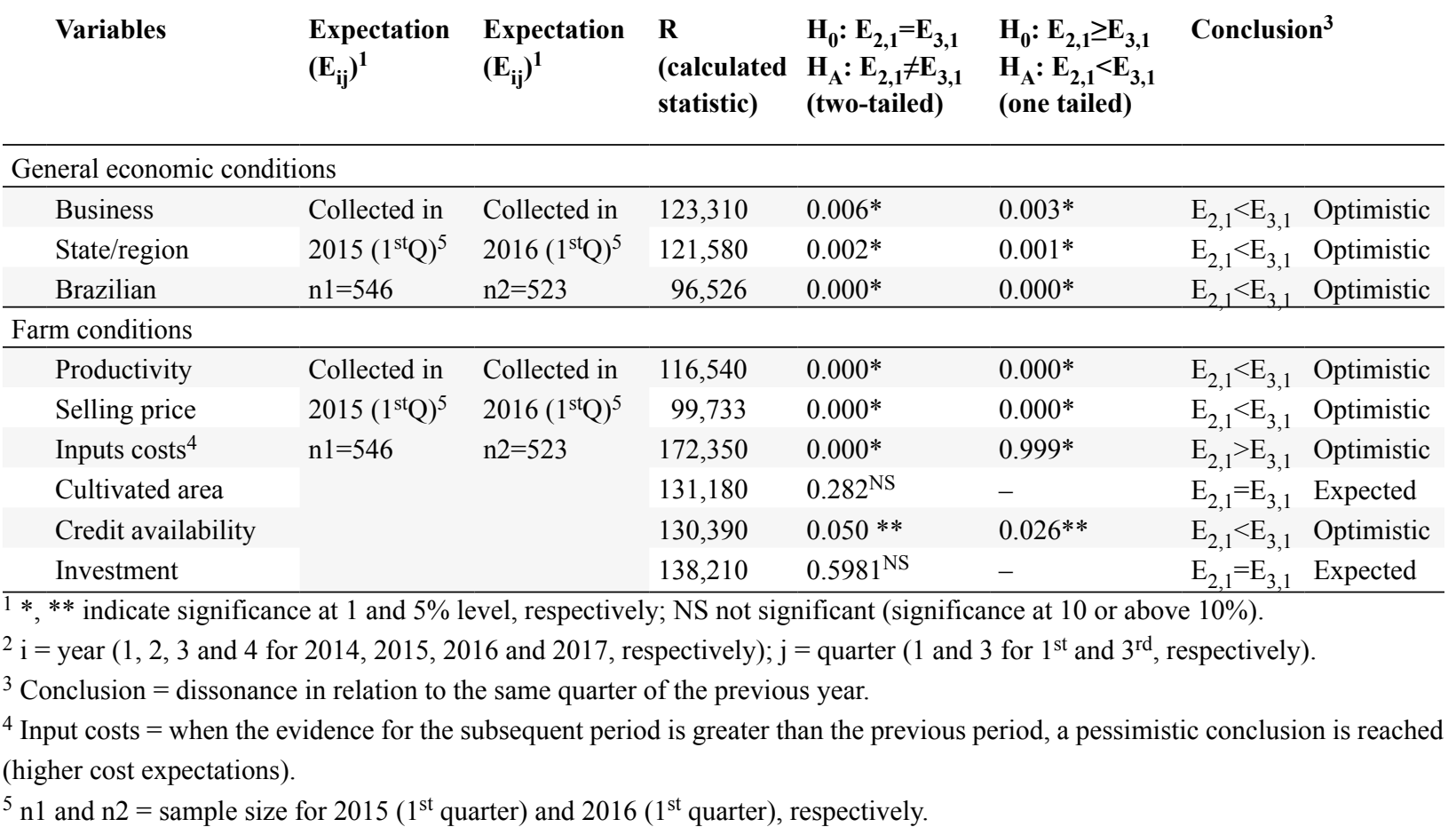

Table 7. Expectation in $2016\left(1^{\text {st }}\right.$ quarter $) \times$ expectation in $2017\left(1^{\text {st }}\right.$ quarter $)-$ agricultural products. ${ }^{1}$

\begin{tabular}{|c|c|c|c|c|c|c|}
\hline Variables & $\begin{array}{l}\text { Expectation } \\
\left(E_{i j}\right)^{2}\end{array}$ & $\begin{array}{l}\text { Expectation } \\
\left(\mathbf{E}_{\mathrm{ij}}\right)^{2}\end{array}$ & $\begin{array}{l}\mathbf{R} \\
\text { (calculated } \\
\text { statistic) }\end{array}$ & $\begin{array}{l}H_{0}: E_{3,1}=E_{4,1} \\
H_{A}: E_{3,1} \neq E_{4,1} \\
\text { (two-tailed) }\end{array}$ & $\begin{array}{l}H_{0}: E_{3,1} \geq E_{4,1} \\
H_{A}: E_{3,1}<E_{4,1} \\
\text { (one-tailed) }\end{array}$ & Conclusion $^{3}$ \\
\hline \multicolumn{7}{|c|}{ General economic conditions } \\
\hline Business & Collected in & Collected in & 121,030 & $0.141^{\mathrm{NS}}$ & - & $\mathrm{E}_{3,1}=\mathrm{E}_{4,1} \quad$ Expected \\
\hline State/region & $2016\left(1^{\text {st }} Q\right)^{5}$ & $2017\left(1^{\text {st }} Q\right)^{5}$ & 107,780 & $0.088^{\mathrm{NS}}$ & $0.044 * *$ & $\mathrm{E}_{3,1}<\mathrm{E}_{4,1} \quad$ Optimistic \\
\hline Brazilian & $\mathrm{n} 1=523$ & $\mathrm{n} 2=441$ & 84,114 & $0.000^{*}$ & $0.000 *$ & $\mathrm{E}_{3,1}<\mathrm{E}_{4,1} \quad$ Optimistic \\
\hline \multicolumn{7}{|l|}{ Farm conditions } \\
\hline Productivity & Collected in & Collected in & 85,024 & $0.000 *$ & $0.000^{*}$ & $\mathrm{E}_{3,1}<\mathrm{E}_{4,1} \quad$ Optimistic \\
\hline Selling price & $2016\left(1^{\mathrm{st}} \mathrm{Q}\right)^{5}$ & $2017\left(1^{\mathrm{st}} \mathrm{Q}\right)^{5}$ & 172,980 & $0.000^{*}$ & $0.999^{\mathrm{NS}}$ & $\mathrm{E}_{3,1}>\mathrm{E}_{4,1} \quad$ Pessimistic \\
\hline Inputs costs 4 & \multirow[t]{4}{*}{$\mathrm{n} 1=523$} & \multirow[t]{4}{*}{$\mathrm{n} 2=441$} & 137,290 & $0.000 *$ & $0.999^{\mathrm{NS}}$ & $\mathrm{E}_{3,1}>\mathrm{E}_{4,1} \quad$ Optimistic \\
\hline Cultivated area & & & 98,114 & $0.000^{*}$ & $0.000^{*}$ & $\mathrm{E}_{3,1}<\mathrm{E}_{4,1} \quad$ Optimistic \\
\hline Credit availability & & & 100,000 & $0.263^{\mathrm{NS}}$ & - & $\mathrm{E}_{3,1}=\mathrm{E}_{4,1} \quad$ Expected \\
\hline Investment & & & 118,400 & $0.328^{\mathrm{NS}}$ & - & $\mathrm{E}_{3,1}=\mathrm{E}_{4,1} \quad$ Expected \\
\hline \multicolumn{7}{|c|}{$1 *, * *$ indicate significance at 1 and $5 \%$ level, respectively; NS not significant (significance at 10 or above $10 \%$ ). } \\
\hline \multirow{2}{*}{\multicolumn{7}{|c|}{$\begin{array}{l}2 \mathrm{i}=\text { year }\left(1,2,3 \text { and } 4 \text { for } 2014,2015,2016 \text { and } 2017 \text {, respectively); } j=\text { quarter ( } 1 \text { and } 3 \text { for } 1^{\text {st }} \text { and } 3^{\text {rd }} \text {, respectively). }\right. \\
{ }^{3} \text { Conclusion = dissonance in relation to the same quarter of the previous year. }\end{array}$}} \\
\hline & & & & & & \\
\hline \multicolumn{7}{|c|}{$\begin{array}{l}{ }^{4} \text { Input costs }=\text { when the evidence for the subsequent period is greater than the previous period, a pessimistic conclusion is reached } \\
\text { (higher cost expectations). }\end{array}$} \\
\hline
\end{tabular}

forecast for the 2014/2015 soybean harvest in the USA was to maintain the record planted area. As a result, the price scenario for the second half was expected to be USD 9 / bu. These values would be below the cost of production in several regions in Brazil. This proves the pessimistic dissonance for costs. 
The descriptive analysis of the results of GEC and FC, mostly pessimistic, gives evidence that the behavior of the soy farmer is sensitive to market variations in order to make investments or not. According to Associação Nacional dos Fabricantes de Veículos Automotores (ANFAVEA) (2020) sales of tractors and harvesters in 2015 compared to 2014 were 32.8 and 39.3\% lower, respectively. National Association for Diffusion of Fertilizers (ANDA) (2021) discloses that in the same period, fertilizer sales were $3.4 \%$ lower.

According to the results presented in Table 5, it is observed that in the analysis of the variables 'cultivated area' and 'investment', the null hypothesis of equality of the notes was not rejected, that is, there is evidence of equality in the notes of the expectations collected in the $1^{\text {st }}$ quarter for the years 2015 and 2016 . As for the other situations, the null hypothesis of equality of the scores was rejected (two-tailed test) and, applying the same tests under one-tailed aspect $(\mathrm{Ei}, 1 \geq \mathrm{Ei}, 1)$ there was dissonance positive for the analysis of most variables.

The analysis of Table 5 shows changes in the expectations of the attributes considered in the years 2016 and 2015. For the three variables of the GEC it was observed that expectations in 2016 were higher than 2015, that is, equivalent to an optimistic scenario. For FC, only the variables related to 'cultivated area' and 'investment' had equivalent expectations (expected). The other attributes of this category were optimistic in 2016 compared to the previous year. It should be noted that just as in 2015 compared to 2014, the 'productivity' attribute continued to be optimistic in 2016 in relation to 2015.

The descriptive analysis of the results of GEC and FC, mostly optimistic, gives evidence that the farmer's behavior is sensitive to market variations in order to make investments within the expected results. According to ANFAVEA (2020) sales of tractors and harvesters in 2016 compared to 2015 were $3.8 \%$ lower for tractors but $14.8 \%$ higher for grain harvesters. ANDA (2021) discloses that in the same period, fertilizer sales were $12.9 \%$ higher.

The results presented in Table 6 show that in the analysis of the variables 'credit availability', 'business / segments' (business), and 'investment', the null hypothesis of equality of notes was not rejected, that is, there is evidence of equality in the expectation scores collected in the $1^{\text {st }}$ quarter for the years 2016 and 2017. For the other situations, the null hypothesis of equality of the scores was rejected (two-tailed test) and, applying the same tests under one-tailed aspect $(\mathrm{Ei}, 1 \geq \mathrm{Ei}, 1)$, there was a balance of dissonances, negative, positive and absent in the analysis of the variables.

Regarding the GEC, the soybean farmer was optimistic in 2017 in relation to 2016. Only the 'business' attribute presented equivalent expectations (expected) for the years 2017 and 2016.

Regarding the farm's conditions, there was pessimism in expectations regarding the sale price of production in 2017 compared to 2016. Productivity followed with optimistic expectations in 2017, as well as the cultivated area and available credit. Furthermore, expectations were shown to be equivalent.

The descriptive analysis of the results of GEC and FC, a little less optimistic in relation to Table 5, again indicates that the farmer's behavior is sensitive to market variations in order to make investments within the expected results. For example: according to ANFAVEA (2020) sales of tractors and combines in 2017 compared to 2016 were $0.9 \%$ lower for tractors, however, $9.8 \%$ higher for grain harvesters. ANDA (2021) discloses that in the same period, fertilizer sales were only $1.0 \%$ higher.

\subsection{Situation 2: comparisons of expectations at the end of the harvest $-3^{\text {rd }}$ quarter}

Situation 2 is known in Brazil as the end of the harvest period and planning for the future harvest. We show the results between the years 2014 and 2015 in Tables 8 and 9. 
variables showed optimistic expectations (business, state and market prices for soybean sales), and the others had pessimistic expectations. From a macroeconomic perspective, comparing the year 2015 with 2014, there was pessimism in expectations regarding the Brazilian economy. On the other hand, these expectations were optimistic in view of the business and state / region variables.

With regard to the conditions of the farm, only the variable referring to the sale price of the production presented optimistic expectations in 2015 compared to 2014. It should be noted that the long-term attribute (productivity) presented, for the first time, pessimistic expectations in the period considered.

Thus, Table 8 confirms the descriptive analyzes in Table 4. Even observing a change in the results from pessimism to optimism in business and state / region, Brazilian economics remained in pessimism. Even with the possible improvement in prices, the behavior of farmers shows signs of continuing to be sensitive to market variations, especially with Brazilian economics. As productivity is apparently analyzed in the long run, the pessimism recorded in Table 8 contributed to the pessimism in investments.

The results presented in Table 8, show that only in the analysis of the variable 'selling prices', the null hypothesis of equality of the notes was not rejected, that is, there is evidence of equality in the notes of the expectations collected in the $3^{\text {rd }}$ quarter for the years of 2015 and 2016. As for the other variables, the null hypothesis of equality of the scores was rejected (two-tailed test) and, applying the same tests under one-tailed aspect (Ei, $3 \geq \mathrm{Ei}, 3$ ), there was a predominance of positive dissonance in the analysis (optimism of expectations).

Regarding the GEC variables, all showed optimistic expectations in 2016 compared to 2015. For the variables referring to the FC, only the available credit showed pessimistic expectations in the analyzed period and the soybean-selling price showed expected expectations. It should be noted that productivity returned to optimistic expectations in 2016. As the productivity variable remained optimistic compared to Table 5, the farmer's behavior was changed to optimism with investment, confirming the analyzes in Table 5 .

\subsection{Situation 3: comparisons of the expectations of the beginning of seeding and the performance of the beginning of the harvest}

Finally, in the third situation, notes for expectations of soybean producers collected in the beginning of planting period ( $3^{\text {rd }}$ quarter) are compared to the notes for the performance of the beginning of the harvest ( $1^{\text {st }}$ quarter), between the years $2014 \times 2015,2015 \times 2016,2016 \times 2017$ (Tables 10 to 12 ).

The results presented in Table 10 show that in the analysis of the variables 'input costs', 'business / segment' and 'state / region', the null hypothesis of equality of notes was not rejected, that is, there is evidence of equality in notes of the expectations collected in the $3^{\text {rd }}$ quarter of 2014 versus performance notes that occurred in the $1^{\text {st }}$ quarter of 2015 . As for the other variables, the null hypothesis of equality of the scores was rejected (two-tailed test) and, applying the same tests under aspect single-tailed (E1.3 $\geq \mathrm{P} 2.1$ ), positive, negative and absent dissonances were observed in the analysis.

For example: according to analysis by CEPEA (2015), the prospects for the Brazilian soy sector in 2014 were confirmed during 2015, with production and export records. The world supply was also a record in 2015 and put pressure on foreign prices. This may have corroborated the expectation regarding the Brazilian economy in 2014 to be greater than the performance in 2015, according to data in Table 9.

According to USDA data, with record production in the United States (106.9 million tons, harvested in the second half of 2014), Brazil (96.2 million tons) and Argentina (60.8 million tons), the world supply reached a historic high. As a consequence, external prices in 2015 fell significantly, but the strong devaluation of the Real reversed this scenario, making it positive for the Brazilian soybean producer. 
Table 10. Expectation in 2014 ( $3^{\text {rd }}$ quarter $) \times$ performance in $2015\left(1^{\text {st }}\right.$ quarter $)-$ soybean. ${ }^{1}$

\begin{tabular}{|c|c|c|c|c|c|c|}
\hline Variables & $\begin{array}{l}\text { Expectation } \\
\left(E_{i j}\right)^{2}\end{array}$ & $\begin{array}{l}\text { Performance } \\
\left(\mathbf{P}_{\mathrm{ij}}\right)^{2}\end{array}$ & $\begin{array}{l}\text { R } \\
\text { (calculated } \\
\text { statistic) }\end{array}$ & $\begin{array}{l}\mathbf{H}_{0}: \mathbf{E}_{1,3}=P_{2,1} \\
H_{A}: E_{1,3} \neq P_{2,1} \\
\text { (bi-tailed) }\end{array}$ & $\begin{array}{l}\mathbf{H}_{0}: \mathbf{E}_{1,3} \geq \mathbf{P}_{2,1} \\
\mathbf{H}_{\mathbf{A}}: \mathbf{E}_{1,3}<\mathbf{P}_{2,1} \\
\text { (one-tailed) }\end{array}$ & Dissonance $^{3}$ \\
\hline \multicolumn{7}{|c|}{ General economic conditions } \\
\hline Business & Collected in & Occurred in & 27,045 & $0.653^{\mathrm{NS}}$ & - & $\mathrm{E}_{1,3}=\mathrm{P}_{2,1} \quad$ Absent \\
\hline State/region & $2014\left(3^{\mathrm{rd}} Q\right)^{5}$ & $2015\left(1^{\text {st }} \mathrm{Q}\right)^{5}$ & 26,066 & $0.777^{\mathrm{NS}}$ & - & $\mathrm{E}_{1,3}=\mathrm{P}_{2,1} \quad$ Absent \\
\hline Brazilian & $\mathrm{n} 1=226$ & $\mathrm{n} 2=234$ & 34,618 & $0.000 *$ & $0.999^{\mathrm{NS}}$ & $\mathrm{E}_{1,3}>\mathrm{P}_{2,1}$ Negative \\
\hline \multicolumn{7}{|l|}{ Farm conditions } \\
\hline Productivity ${ }^{4}$ & Collected in & Occurred in & 37,873 & $0.000 *$ & $0.999^{\mathrm{NS}}$ & $\mathrm{E}_{1,3}>\mathrm{P}_{2,1} \quad$ Negative \\
\hline Selling price & $2014\left(3^{\mathrm{rd}} Q\right)^{5}$ & $2015\left(1^{\mathrm{st}} \mathrm{Q}\right)^{5}$ & 12,756 & $0.000 *$ & $0.000 *$ & $\mathrm{E}_{1,3}<\mathrm{P}_{2,1} \quad$ Positive \\
\hline Inputs costs & $\mathrm{n} 1=226$ & $\mathrm{n} 2=234$ & 26,436 & $0.997^{\mathrm{NS}}$ & - & $\mathrm{E}_{1,3}=\mathrm{P}_{2,1} \quad$ Absent \\
\hline Cultivated area & & & 23,309 & $0.008^{*}$ & $0.004 *$ & $\mathrm{E}_{1,3}<\mathrm{P}_{2,1} \quad$ Positive \\
\hline Credit availability & & & 35,330 & $0.000^{*}$ & $0.999^{\mathrm{NS}}$ & $E_{1,3}>P_{2,1} \quad$ Negative \\
\hline Investment & & & 22,703 & $0.007^{*}$ & $0.003 *$ & $\mathrm{E}_{1,3}<\mathrm{P}_{2,1} \quad$ Positive \\
\hline \multicolumn{7}{|c|}{$1 *$ indicate significance at $1 \%$ level; NS not significant (significance at 10 or above $10 \%$ ). } \\
\hline \multicolumn{7}{|c|}{$2 \mathrm{i}=$ year $\left(1,2,3\right.$ and 4 for 2014, 2015, 2016 and 2017, respectively); $\mathrm{j}=$ quarter ( 1 and 3 for $1^{\text {st }}$ and $3^{\text {rd }}$, respectively). } \\
\hline \multirow{3}{*}{\multicolumn{7}{|c|}{$\begin{array}{l}{ }^{3} \text { Positive dissonance }=\text { expectation }<\text { performance }(\text { except for 'inputs costs' that the relationship is inverse, that is, expectation }> \\
\text { performance); negative dissonance }=\text { expectation }>\text { performance }(\text { except for 'inputs costs' where the relationship is inverse, that is, } \\
\text { expectation }<\text { performance) } \text {; missing dissonance }=\text { performance }=\text { expectation. }\end{array}$}} \\
\hline & & & & & & \\
\hline & & & & & & \\
\hline \multicolumn{7}{|c|}{${ }^{4}$ Productivity was used as a 'proxy' variable for investment made (performance). } \\
\hline \multicolumn{7}{|c|}{${ }^{5} \mathrm{n} 1$ and $\mathrm{n} 2=$ sample size for 2014 ( $3^{\text {rd }}$ quarter $)$ and 2015 ( $1^{\text {st }}$ quarter $)$, respectively. } \\
\hline
\end{tabular}

Table 11. Expectation in $2015\left(3^{\text {rd }}\right.$ quarter $) \times$ performance in $2016\left(1^{\text {st }}\right.$ quarter $)-$ soybean. ${ }^{1}$

\begin{tabular}{|c|c|c|c|c|c|c|}
\hline Variables & $\begin{array}{l}\text { Expectation } \\
\left(E_{i j}\right)^{2}\end{array}$ & $\begin{array}{l}\text { Performance } \\
\left(\mathbf{P}_{\mathrm{ij}}\right)^{2}\end{array}$ & $\begin{array}{l}\text { R } \\
\text { (calculated } \\
\text { statistic) }\end{array}$ & $\begin{array}{l}\mathbf{H}_{0}: \mathbf{E}_{2,3}=\mathbf{P}_{3,1} \\
\mathbf{H}_{\mathrm{A}}: \mathbf{E}_{2,3} \neq \mathbf{P}_{3,1} \\
\text { (Two-tailed) }\end{array}$ & $\begin{array}{l}\mathbf{H}_{0}: \mathbf{E}_{2,3} \geq \mathbf{P}_{3,1} \\
\mathbf{H}_{\mathbf{A}}: \mathbf{E}_{2,3}<\mathbf{P}_{3,1} \\
\text { (One-tailed) }\end{array}$ & Dissonance $^{3}$ \\
\hline \multicolumn{7}{|c|}{ General economic conditions } \\
\hline Business & Collected in & Occurred in & 39,231 & $0.000^{*}$ & $0.999^{\mathrm{NS}}$ & $\mathrm{E}_{2,3}>\mathrm{P}_{3,1} \quad$ Negative \\
\hline State/region & $2015\left(3^{\mathrm{rd}} Q\right)^{5}$ & $2016\left(1^{\text {st }} Q\right) 5$ & 36,659 & $0.000^{*}$ & $0.998^{\mathrm{NS}}$ & $\mathrm{E}_{2,3}>\mathrm{P}_{3,1} \quad$ Negative \\
\hline Brazilian & $\mathrm{N} 1=239$ & $\mathrm{~N} 2=262$ & 32,431 & $0.447^{\mathrm{NS}}$ & - & $\mathrm{E}_{2,3}=\mathrm{P}_{3,1} \quad$ Absent \\
\hline \multicolumn{7}{|l|}{ Farm conditions } \\
\hline Productivity ${ }^{4}$ & Collected in & Occurred in & 37,843 & $0.000 *$ & $0.999^{\mathrm{NS}}$ & $\mathrm{E}_{2,3}>\mathrm{P}_{3,1} \quad$ Negative \\
\hline Selling price & $2015\left(3^{\mathrm{rd}} Q\right)^{5}$ & $2016\left(1^{\text {st }} \mathrm{Q}\right)^{5}$ & 36,581 & $0.000 *$ & $0.999^{\mathrm{NS}}$ & $E_{2,3}>P_{3,1} \quad$ Negative \\
\hline Inputs costs & \multirow[t]{4}{*}{$\mathrm{n} 1=239$} & \multirow[t]{4}{*}{$\mathrm{n} 2=262$} & 41,386 & $0.000^{*}$ & $0.999^{\mathrm{NS}}$ & $\mathrm{E}_{2,3}>\mathrm{P}_{3,1}$ Positive \\
\hline Cultivated area & & & 20,408 & $0.000^{*}$ & $0.000^{*}$ & $\mathrm{E}_{2,3}<\mathrm{P}_{3,1} \quad$ Positive \\
\hline Credit availability & & & 33,428 & $0.032 * *$ & $0.984^{\mathrm{NS}}$ & $E_{2,3}>P_{3,1} \quad$ Negative \\
\hline Investment & & & 22,464 & $0.000^{*}$ & $0.000^{*}$ & $\mathrm{E}_{2,3}<\mathrm{P}_{3,1} \quad$ Positive \\
\hline \multicolumn{7}{|c|}{$1 *$ indicate significance at $1 \%$ level; NS not significant (significance at 10 or above $10 \%$ ). } \\
\hline \multicolumn{7}{|c|}{$2 \mathrm{i}=$ year $\left(1,2,3\right.$ and 4 for 2014, 2015, 2016 and 2017, respectively); $\mathrm{j}=$ quarter ( 1 and 3 for $1^{\text {st }}$ and $3^{\text {rd }}$, respectively). } \\
\hline \multirow{3}{*}{\multicolumn{7}{|c|}{$\begin{array}{l}{ }^{3} \text { Positive dissonance }=\text { expectation }<\text { performance (except for 'inputs costs' that the relationship is inverse, that is, expectation }> \\
\text { performance); negative dissonance }=\text { expectation }>\text { performance (except for 'inputs costs' where the relationship is inverse, that is, } \\
\text { expectation }<\text { performance); missing dissonance }=\text { performance }=\text { expectation. }\end{array}$}} \\
\hline & & & & & & \\
\hline & & & & & & \\
\hline \multicolumn{7}{|c|}{${ }_{5}^{4}$ Productivity was used as a proxy variable for investment (performance). } \\
\hline \multicolumn{7}{|c|}{${ }^{5} \mathrm{n} 1$ and n2: sample size for 2015 ( $3^{\text {rd }}$ quarter) and 2016 ( $1^{\text {st }}$ quarter), respectively. } \\
\hline
\end{tabular}


According to analyzes by CEPEA (2015), since the end of the first half of 2014, the relationship between costs and expected revenue indicated a better situation for soybeans than for competing crops in the area, such as corn and cotton. This justified the expansion of oilseed crops, which, according to Companhia Nacional de Abastecimento (CONAB) (2020), occupied more than 32.1 million hectares, also a record. The exchange rate and strong demand were important for prices to be sustained in Brazil, even with fluctuations throughout the year. In most regions, soybean grain prices rose in the first quarter of 2015. Thus, it can be understood (Table 10), that in a microeconomic context (farm conditions), expectations were confirmed for input costs (expected), presenting a positive performance for the variables related to soybean sale prices, planted area and investment.

The results presented in Table 11 show that in the analysis of the variable 'economic situation in Brazil', the null hypothesis of equality of grades was not rejected, that is, there is evidence of equality in the grades of expectations collected in the third quarter of 2015 versus performance scores in the $1^{\text {st }}$ quarter of 2016. For the other variables, the null hypothesis of equality of scores was rejected (two-tailed test) and, applying the same tests under one-tailed aspect $(\mathrm{E} 2.3 \geq \mathrm{P} 3.1)$, the predominance of negative dissonance was observed in the analysis.

When conducting a fundamentalist analysis, it is observed that soybean prices rose sharply in the Brazilian market in 2016, reaching records, according to analyzes by CEPEA (2016a). The impulse came mainly from the retracted posture of producers, who negotiated a large part of the 2015/16 harvest in advance, still in mid2015. In addition, the heated (domestic and foreign) demand, favored by the appreciation of the dollar against the Real, contributed raised prices. This scenario may have contributed to the creation of expectations in the $3^{\text {rd }}$ quarter of 2015 , well beyond the performance observed in early 2016, by soybean producers. As shown in Table 9, in a macro context, this is consistent with the negative dissonances observed for the variables related to the business itself and the region where the interviewed producers operate.

It is noteworthy that the global production of soybeans in the $2015 / 16$ crops decreased by $2 \%$ compared to $2014 / 15$, according to USDA data. This possibly influenced the fact that the performance at the beginning of 2016 was lower than the expectations of the producers interviewed at the end of 2015 regarding productivity (Table 11), in a micro context (farm conditions).

In this context, it is also worth mentioning that the beginning of 2015 was marked by the movement of high prices due to the unfavorable climate that affected part of the crops (CEPEA 2016b). This may also have influenced a very high expectation on the part of the farmers interviewed at the end of 2015. Although 2016 was marked by record prices, the negative price performance observed in early 2016 (Table 11) may be closely related to excessive optimism of the interviewed producers due to the aforementioned price increase. Also, there was a positive performance for investments. Possibly, the reduced production of the 2015/16 crops may have been indicative of the need for higher grades for investment performance in early 2016 compared to the end of 2015 by respondents.

The results presented in Table 12 show that in the analysis of the variables 'input costs' and 'cultivated area' the null hypothesis of equality of grades was not rejected, that is, there is evidence of equality in the grades of expectations collected in the third quarter of the year of 2016 versus the performance scores in the $1^{\text {st }}$ quarter of 2017. For the other variables, the null hypothesis of equality of the scores was rejected (twotailed test) and, applying the same tests under one-tailed aspect $(\mathrm{E} 3.3 \geq \mathrm{P} 4,1)$, there was a predominance of negative dissonance in the analysis.

The 2016/17 Brazilian harvest totaled 114 million tons of soybeans (record), 18\% above that produced in the 2015/16 harvest, according to data from the USDA (2020) and Conab (2020). In addition to the greater offer, national values were pressured by the devaluation of the dollar against the Real, which reduced the values received by the producer. In this sense, for the macro context, the performance was negative for the three related variables: business and region of the soy farmers interviewed as well as the Brazilian economy. 
Table 12. Expectation in $2016\left(3^{\text {rd }}\right.$ quarter $) \times$ performance in $2017\left(1^{\text {st }}\right.$ quarter $)$ - soybean. ${ }^{1}$

\begin{tabular}{|c|c|c|c|c|c|c|}
\hline Variables & $\begin{array}{l}\text { Expectation } \\
\left(\mathrm{E}_{\mathrm{ij}}\right)^{2}\end{array}$ & $\begin{array}{l}\text { Performance } \\
\left(\mathbf{P}_{\mathrm{ij}}\right)^{2}\end{array}$ & $\begin{array}{l}\text { R } \\
\text { (calculated } \\
\text { statistic) }\end{array}$ & $\begin{array}{l}\mathbf{H}_{0}: \mathbf{E}_{3,3}=\mathbf{P}_{4,1} \\
\mathbf{H}_{\mathrm{A}}: \mathbf{E}_{3,3} \neq \mathbf{P}_{4,1} \\
\text { (two-tailed) }\end{array}$ & $\begin{array}{l}\mathbf{H}_{0}: \mathbf{E}_{3,3} \geq \mathbf{P}_{4,1} \\
\mathbf{H}_{\mathrm{A}}: \mathbf{E}_{3,3}<\mathbf{P}_{4,1} \\
\text { (one-tailed) }\end{array}$ & Dissonance $^{3}$ \\
\hline \multicolumn{7}{|c|}{ General economic conditions } \\
\hline Business & Collected in & Occurred in & 50,385 & $0.000^{*}$ & $0.999^{\mathrm{NS}}$ & $\mathrm{E}_{3,3}>\mathrm{P}_{4,1} \quad$ Negative \\
\hline State/region & $2016\left(3^{\mathrm{rd}} Q\right)^{5}$ & $2017\left(1^{\text {st }} Q\right)^{5}$ & 47,786 & $0.000^{*}$ & $0.999^{\mathrm{NS}}$ & $\mathrm{E}_{3,3}>\mathrm{P}_{4,1} \quad$ Negative \\
\hline Brazilian & $\mathrm{n} 1=273$ & $\mathrm{n} 2=261$ & 55,348 & $0.000 *$ & $0.999^{\mathrm{NS}}$ & $\mathrm{E}_{3,3}>\mathrm{P}_{4,1} \quad$ Negative \\
\hline \multicolumn{7}{|l|}{ Farm conditions } \\
\hline Productivity ${ }^{4}$ & Collected in & Occurred in & 26,428 & $0.000^{*}$ & $0.000^{*}$ & $\mathrm{E}_{3,3}<\mathrm{P}_{4,1} \quad$ Positive \\
\hline Selling price & $2016\left(3^{\text {rd }} Q\right) 5$ & $2017\left(1^{\text {st }} Q\right)^{5}$ & 49,762 & $0.000^{*}$ & $0.999^{\mathrm{NS}}$ & $\mathrm{E}_{3,3}>\mathrm{P}_{4,1} \quad$ Negative \\
\hline Inputs costs & \multirow[t]{4}{*}{$\mathrm{n} 1=273$} & \multirow[t]{4}{*}{$\mathrm{n} 2=261$} & 32,612 & $0.066^{\mathrm{NS}}$ & - & $\mathrm{E}_{3,3}=\mathrm{P}_{4,1} \quad$ Absent \\
\hline Cultivated area & & & 34,440 & $0.3313^{\mathrm{NS}}$ & - & $\mathrm{E}_{3,3}=\mathrm{P}_{4,1} \quad$ Absent \\
\hline Credit availability & & & 26,785 & $0.000^{*}$ & $0.000^{*}$ & $\mathrm{E}_{3,3}<\mathrm{P}_{4,1} \quad$ Positive \\
\hline Investment & & & 55,134 & $0.000^{*}$ & $0.000 *$ & $\mathrm{E}_{3,3}<\mathrm{P}_{4,1} \quad$ Positive \\
\hline \multicolumn{7}{|c|}{$1 *$ indicate significance at $1 \%$ level; NS not significant (significance at 10 or above $10 \%$ ). } \\
\hline \multicolumn{7}{|c|}{${ }^{2} \mathrm{i}=\operatorname{year}\left(1,2,3\right.$ and 4 for 2014, 2015, 2016 and 2017, respectively); $\mathrm{j}=$ quarter ( 1 and 3 for $1^{\text {st }}$ and $3^{\text {rd }}$, respectively). } \\
\hline \multirow{3}{*}{\multicolumn{7}{|c|}{$\begin{array}{l}3 \text { positive dissonance }=\text { expectation }<\text { performance }(\text { except for 'inputs costs' where the relationship is inverse, that is, expectation } \\
>\text { performance); negative dissonance }=\text { expectation }>\text { performance }(\text { except for 'inputs costs' where the relationship is inverse, that } \\
\text { is, expectation }<\text { performance) } \text {; missing dissonance }=\text { performance }=\text { expectation. }\end{array}$}} \\
\hline & & & & & & \\
\hline & & & & & & \\
\hline \multicolumn{7}{|c|}{4 Productivity was used as a 'proxy' variable for investment made (performance). } \\
\hline \multicolumn{7}{|c|}{${ }^{5} \mathrm{n} 1$ and $\mathrm{n} 2=$ sample size for 2016 ( $3^{\text {rd }}$ quarter$)$ and 2017 ( $1^{\text {st }}$ quarter $)$, respectively. } \\
\hline
\end{tabular}

The fall in prices may have been a factor of great relevance for the performance of the Brazilian economic scenario to present a negative dissonance. On the other hand, these events also influenced some variables in the micro scenario, which showed both negative and positive dissonance.

The 2017 season was the largest area cultivated with soy in Brazil (until this year) as well as in the United States and Argentina. Also, productivity was well above average in these countries. In this scenario, according to surveys by Cepea (2017), oilseed prices dropped in Brazil in 2017, returning to the lowest real levels since 2011. Given this, in the micro context (farm conditions), it can be observed (Table 12) that the performance of the soybean prices of the producers interviewed at the beginning of 2017 were lower than the expectations collected at the end of 2016. On the other hand, the performance of the area and productivity variables showed a positive performance.

\section{Conclusions}

\subsection{First question}

From Table 13, with the results of situations 1 (item 5.1) and 2 (item 5.2), it is possible to observe that the Brazilian economy variable clearly defines investment behaviors. In terms of theoretical contribution, it means that factors related to general economic conditions are defined by the theory of planned purchase. It seems that the sensitivity to macroeconomic factors directly reflects the 'mood' of farmers to decide whether or not to invest in their farms. Regarding the Farms condition, only the productivity factor was related to the planned purchase theory. This is the microeconomic factor that is reflected in the farmer's decision process to define his future investments. Brazilian economy and Productivity are long-term decision factors. We can explain these long-term decision factors through the literature on motivated beliefs and reasoning (Epley and Gilovich, 2016). Motivated beliefs will respond to the costs, benefits and risks involved in maintaining self-views and worldviews (Bénabou and Tirole, 2016). Therefore, Brazilian economy and Productivity can mean self-sustainable business and social cognitions in the sector (Bénabou and Tirole, 2016). The 
Table 13. Summary of situations 1 and 2 - expectations.

\begin{tabular}{|c|c|c|c|c|c|c|}
\hline \multicolumn{2}{|l|}{ Scenarios } & $\begin{array}{c}2015 \times 2014 \\
1^{\text {st }} Q \\
\text { (Table } 4)\end{array}$ & $\begin{array}{c}2015 \times 2014 \\
3^{\text {rd } Q} \\
\text { (Table } 7)\end{array}$ & $\begin{array}{c}2016 \times 2015 \\
1^{\text {st }} Q \\
(\text { Table } 5)\end{array}$ & $\begin{array}{c}2016 \times 2015 \\
3^{\text {rd } Q} \\
\text { (Table } 8)\end{array}$ & $\begin{array}{c}2017 \times 2016 \\
1^{\text {st }} Q \\
(\text { Table 6) }\end{array}$ \\
\hline \multicolumn{2}{|c|}{ General economic conditions } & - & + & + & + & + \\
\hline \multicolumn{2}{|c|}{ Farm conditions } & - & - & + & + & + \\
\hline \multirow[t]{3}{*}{ Spotlight } & Brazilian economy & - & - & + & + & + \\
\hline & Productivity & + & - & + & + & + \\
\hline & Selling price & - & + & + & $=$ & - \\
\hline \multicolumn{2}{|c|}{ Investment } & - & - & $=$ & + & $=$ \\
\hline
\end{tabular}

leaders who develop public policies regarding investment credit and agricultural insurance should look at these factors, Brazil's economy and productivity, to define new products, services and ways of protecting agribusiness and farmers in Brazil.

\subsection{Second question}

There is evidence that the economic concepts that measure farmer confidence are present in this article. However, when looking at Table 14, we found data that should be studied in greater depth in other studies. When comparing expectation with performance (Tables 10,11 and 12) it is noted that performance has always been more pessimistic than expectations prior to the past period. Even so, the perception of continuing to invest was maintained with optimism. Expectations play a key role in Keynes's theory because he considers that investment and consumption decisions derive largely from changes in expectations. Changes in expectations can be explained by Brazilian economic, Productivity and Selling price. Marzilli Ericson and Fuster (2011) carry out two experiments that show that the reference points are determined, at least in part, by expectations, which can be confirmed, in part, by this study.

As suggestions for future studies towards the improvement of the model, it is proposed to apply it in other regions and in other periods.

Table 14. Situation summary 3 - expectations vs performance.

\begin{tabular}{|c|c|c|c|c|}
\hline \multicolumn{2}{|c|}{ Scenarios } & $\begin{array}{c}2014 \times 2015 \\
3^{\text {rd }} Q \times 1^{\text {st }} Q \\
(\text { Table } 9)\end{array}$ & $\begin{array}{l}2015 \times 2016 \\
3^{\text {rd }} Q \times 1^{\text {st }} Q \\
(\text { Table } 10)\end{array}$ & $\begin{array}{c}2016 \times 2017 \\
3^{\text {rd }} Q \times 1^{\text {st }} Q \\
\text { (Table 11) }\end{array}$ \\
\hline \multicolumn{2}{|c|}{ General economic conditions } & $=$ & - & - \\
\hline \multicolumn{2}{|c|}{ Farm conditions } & - & - & $=$ \\
\hline \multirow[t]{3}{*}{ Spotlight } & Brazilian economic & - & $=$ & - \\
\hline & Productivity & - & - & + \\
\hline & Selling price & + & - & - \\
\hline \multicolumn{2}{|c|}{ Investment } & + & + & + \\
\hline
\end{tabular}




\section{Conflicts of interest}

There is no conflict of interest

\section{References}

Associação Nacional dos Fabricantes de Veículos Automotores (ANFAVEA). 2020. Estatísticas. Available at: https://www.anfavea.com.br/estatisticas

Associação Nacional para difusão de Adubos (ANDA). 2021. Arquivos para download. Available at: https:// www.anda.org.br/arquivos

Bénabou, R. and J. Tirole. 2016. Mindful economics: the production, consumption, and value of beliefs. Journal of Economic Perspectives 30(3): 141-164. https://doi.org/10.1257/jep.30.3.141

Bussab, W.O. and P.A. Morettin. 2006. Estatística Básica. Editora Saraiva, São Paulo, Brazil.

Centro de Estudos Avançados em Economia Aplicada (CEPEA). 2015. Soja, Agromensal Available at: https:// www.cepea.esalq.usp.br/br/categoria/agromensal.aspx

Centro de Estudos Avançados em Economia Aplicada (CEPEA) da Escola Superior de Agricultura Luiz de Queiroz da Universidade de São Paulo (ESALQ/USP). 2016a. Soja, Agromensal. Available at: https://www.cepea.esalq.usp.br/br/categoria/agromensal.aspx

Centro de Estudos Avançados em Economia Aplicada (CEPEA). 2016b. Soja, Agromensal Available at: https://www.cepea.esalq.usp.br/br/categoria/agromensal.aspx

Centro de Estudos Avançados em Economia Aplicada (CEPEA). 2017. Soja, Agromensal Available at: https:// www.cepea.esalq.usp.br/br/categoria/agromensal.aspx

Chernavsky, E. 2018. Os índices de confiança ajudam a elaborar previsões econômicas confiáveis? No. 2383. Texto para Discussão. Available at: https://www.ipea.gov.br/portal/index.php?option=com content\&view=article \&id=33157:os-indices-de-confianca-ajudam-a-elaborar-previsoes-economicasconfiaveis\&catid $=411: 2018 \&$ directory $=1$

Companhia Nacional de Abastecimento (CONAB). 2020. Sistema de Informação (SIC). Available at: https:// esic.cgu.gov.br/sistema/relatorios/anual/downloadDados.aspx

Dos Santos Amorim, G., C. Weber, N.L. Costa and D.A. Coronel. 2019. Cadeias globais de valor: a inserção do agronegócio Brasileiro. Available at: https://online.unisc.br/acadnet/anais/index.php/sidr/article/ view/19174

Epley, N. and T. Gilovich. 2016. The mechanics of motivated reasoning. Journal of Economic Perspectives 30(3): 133-40. https://doi.org/10.1257/jep.30.3.133

Fishbein, M. and I. Ajzen. 2010. Predicting and changing behavior: the reasoned action approach. Taylor \& Francis Group, New York, NY, USA.

Food and Agriculture Organization of the United Nations (FAO). 2020. Statistics. FAO. Rome, Italy. Available at: https://www.fao.org/statistics/en/

Ghosh, S. 2020. Consumer confidence and consumer spending in Brazil: a nonlinear autoregressive distributed lag model analysis. Arthaniti: Journal of Economic Theory and Practice 20(1): 53-85. https://doi. org/10.1177/0976747919898906

Graminho, F.M. 2015. Sentimento e macroeconomia: uma análise dos índices de confiança no Brasil. Brazilian Central Bank, trabalhos para discussão, 408. Available at: https://www.bcb.gov.br/pec/ wps/port/wps408.pdf

Haberli Junior, C., T. Oliveira, M. Yanaze and E.E. Spers. 2019a. Performance, farmer perception, and the routinisation (RO) moderation on ERP post-implementation. Heliyon 5(6): e01784. https://doi. org/10.1016/j.heliyon.2019.e01784

Haberli Junior, C., T. Oliveira, M. Yanaze. 2019b. The adoption stages (evaluation, adoption, and routinisation) of ERP systems with business analytics functionality in the context of farms. Computers and Electronics in Agriculture 156: 334-348. https://doi.org/10.1016/j.compag.2018.11.028 
Jones, J.W., J.M. Antle, B. Basso, K.J. Boote, R.T. Conant, I. Foster, H.C.J. Godfray, M. Herrero, R.E. Howitt, S. Janssen, B.A. Keating, R. Munoz-Carpena, C.H. Porter, C. Rosenzweig and T.R. Wheeler. 2017. Brief history of agricultural systems modeling. Agricultural Systems 155: 240-254. https:// doi.org/10.1016/j.agsy.2016.05.014

Junior, C.H., T. Oliveira and M. Yanaze. 2019. The adoption stages (evaluation, adoption, and routinisation) of ERP systems with business analytics functionality in the context of farms. Computers and Electronics in Agriculture 156: 334-348. https://doi.org/10.1016/j.compag.2018.11.028

Keynes, J. 1936. The general theory of employment, interest and money. Macmillan, London, UK.

Larson, R. and B. Farber. 2010. Elementary statistics. Pearson Education, North York, ON, Canada.

Los, V. and D. Ocheretin. 2019. Prediction of business confidence index based on a system of economic indicators. CEUR Workshop Proceedings 2422: 237-248. https://doi.org/10.1051/shsconf/20196506003

Ludvigson, S.C. 2004. Consumer confidence and consumer spending. Journal of Economic Perspectives 18(2): $29-50$.

Marzilli Ericson, K.M. and A. Fuster. 2011. Expectations as endowments: evidence on reference-dependent preferences from exchange and valuation experiments. Quarterly Journal of Economics 126(4): 1879-1907. https://doi.org/10.1093/qje/qjr034

North, D. 1990. Institutions and their consequences for economic performance. In: K.S. Cook and M. Levi (eds.) The limits of rationality. University of Chicago Press, Chicago, IL, USA, pp. 383-401.

Nuthall, P.L. and K.M. Old. 2018. Intuition, the farmers' primary decision process. A review and analysis. Journal of Rural Studies 58: 28-38. https://doi.org/10.1016/j.jrurstud.2017.12.012

Organisation for Economic Cooperation and Development (OECD) and Food and Agriculture Organisation (FAO). 2011. OCDE-FAO Perspectivas agrícolas 2011. OECD-FAO, Paris, France, 224 pp. Available at: https://www.oecd-ilibrary.org/agriculture-and-food/ocde-fao-perspectivas-agricolas-2011-2020_ agr_outlook-2011-es

R Core Team. 2018. R: A language and environment for statistical computing. R Foundation for Statistical Computing, Vienna, Austria.

Siegel, S. 1956. Nonparametric statistics for the behavioral sciences. Mc Graw-Hill Book Company, Inc., New York, NY, USA, 312 pp.

Simões, J.E.M., M.J.T. Diniz, M.B. Diniz and J.N. De Oliveira Junior. 2016. Índice de expectativas do consumidor no Brasil: uma análise do poder preditivo no período entre 2001 e 2014. Planejamento e Politicas Públicas 47: 187-218. Available at: http://repositorio.ipea.gov.br/bitstream/11058/7371/1/ ppp_n47_índice.pdf

Turner V, J.L. 2018. Risk and return comparisons of pre-harvest marketing strategies. MSc-thesis, University of Arkansas, Fayetteville, AR, USA.

United States Department of Agriculture - Foreign Agriculture Service (USDA-FAS). 2020. Data \& analysis. USDA-FAS, Washington, DC, USA. Available at: https://www.fas.usda.gov/data 